\title{
Identification of phytoplankton species using Hermite transform
}

\author{
Castro-Valdez A. and Álvarez-Borrego J.
}

CICESE, Optics Department, Applied Physics Division, Carretera Ensenada-Tijuana No. 3918, Fraccionamiento Zona Playitas, Ensenada, México, C. P. 22860

Received: 14.02 .2018

\begin{abstract}
We apply a Hermite transform joint with a classical correlation analysis to successfully recognize phytoplankton species even in such complicated cases when the relevant images reveal the patterns of inhomogeneous illumination and natural distortions. The images of phytoplankton species are divided into two groups consisting of 30 samples each. Those belonging to the first group are the images with neither inhomogeneous illumination nor noise, while the second one embraces the images with the background noise, inhomogeneous illumination and real distortions. We find the optimal Hermite-transform order to be used in finding correlations among the images. It is given by a so-called 'peak correlation energy' metric. Using the images modified by the Hermite transform with a classical Vander-Lugt filter, we are able to distinguish all the phytoplankton species in the test images. A classical composite filter is also applied to the two groups of images. For the first group, the composite filter is created using different patterns of illumination of the same species. In the second group, this filter is composed using various specimens of the same species in order to identify a specific species. In the both cases, the Hermite transform joined with the classical correlation analysis can distinguish all the phytoplankton species.
\end{abstract}

Keywords: Hermite transform, classical composite filter, Pearson correlation, pattern recognition.

PACS: $42.79 . \mathrm{Hp}$

UDC: 535.361

\section{Introduction}

Recognition of images and patterns is something that human beings do daily if not every minute. Many images and patterns are interpreted as indications or warnings. Perhaps, unconsciously, we analyze and perform counting, search and classification of what we see. Studies for the recognition of complex images or patterns have formed a unique area of optics. It is the use of mathematical transformations that has made these applications possible. Their specific forms vary from a classic filter [1] to multiple filters suggested in contemporary optics. In particular, image correlation analysis has been successfully used in engineering [2-4], identification of marine species [5-9], inclusion bodies [10], carcinogenic spots on the skin [11], etc.

The properties required from different transformations and the reasons for applying them have to do with obtaining of invariant correlations. Often the images under test are not similar to each other. For instance, carcinogenic spots on the skin or images of histological cuts do not have the same shape [12], whereas their morphology is notably varied. The need in identification and analysis of these images has favoured the studies of novel mathematical approaches. In biomedical applications, a Hermite transform with neural networks has been used for iris recognition [13], estimation in cardiac computed tomography [14] and fetal echocardiography [15]. It has also been applied to reducing noise and fusing images [16, 17]. 
On the other hand, little research has been conducted on this transform with the aim of optimizing image correlation [18]. The Hermite transform has been used in image indexing, using a method of texture content and edge detection for extracting characteristic information from images [19]. In this respect, the Hermite functions have been used to perform the correlation analysis of simulated radar signals basing on neural networks [20]. However, no correlation technique has ever been developed that involves the 2D Hermite transform. In principle, this approach can be intended to identify the objects with such distortions as noises, or varying illumination conditions, image scales and image displacements.

In the present work we consider the correlation analysis that involves the 2D Hermite transform. We find out the optimal order of the transform and then subject the images to the correlation analysis. We prefer to call this technique as a Hermite correlation. It is compared with the classical correlation technique using an important practical example, the problem of recognizing different phytoplankton species.

\section{2D Hermite transform and peak correlation energy metric}

The Hermite transform is a particular case of polynomial transforms. It represents in fact an image description model [21]. In this sense the Hermite transform is nothing but an image-decomposition technique. It includes the two following steps. First an input image $L(x, y)$ is multiplied by a window function $v(x-p, y-q)$. To describe the entire signal, this process takes several positions $(p, q)$ over the image forming a sampling lattice $S$, where $(x, y)$ are the coordinates of a pixel. The input signal is multiplied by the window function $v(x-p, y-q)$ at the positions $p$ and $q$, and the original signal is given by

$$
L(x, y)=\frac{1}{W(x, y)} \sum_{(p, q) \in S} L(x, y) v(x-p, y-q),
$$

where $W(x, y)=\sum_{(p, q) \in S} v(x-p, y-q)$ is the weighting function. This function must be different from zero for all the coordinates $(x, y)$.

Second, the signal is described using the window function and the polynomials $G_{m, n-m}(x, y)$, with the polynomial grades $m$ and $n-m$. A standard orthogonality condition

$$
\int_{-\infty}^{\infty} \int_{-\infty}^{\infty} v^{2}(x, y) G_{m, n-m}(x, y) G_{l, k-l}(x, y) d x d y=\delta_{n l} \delta_{m k}
$$

must be satisfied for $n, l=0, \ldots, \infty$ and $m, k=0, \ldots, \infty$, with $\delta_{n l}$ and $\delta_{m k}$ denoting the Kronecker delta functions.

In a particular case of Hermite transform, one uses the Gaussian window function:

$$
v(x, y)=\frac{1}{\sqrt{\sqrt{\pi} \sigma}} \exp \left(-\frac{\left(x^{2}+y^{2}\right)}{2 \sigma^{2}}\right),
$$

where $\sigma$ is the standard deviation (the case $\sigma=1$ can be specified for convenience). Then the associated orthogonal polynomials represent the Hermite polynomials $H_{n}(x)$ :

$$
G_{m, n-m}(x, y)=\frac{1}{\sqrt{2^{n}(n-m) ! m !}} H_{m}\left(\frac{x}{\sigma}\right) H_{n-m}\left(\frac{y}{\sigma}\right) .
$$

Ukr. J. Phys. Opt. 2018, Volume 19, Issue 2 
In either case, the polynomial coefficients $L_{m, n-m}(p, q)$ are calculated by convoluting the original image $L(x, y)$ with the filter function $D_{m, n-m}(x, y)=G_{m, n-m}(x, y) v^{2}(-x,-y)$, which is followed by subsampling at every position $(p, q)$ of the sampling lattice $S$. In other words, we have

$$
L_{m, n-m}(p, q)=\int_{-\infty}^{\infty} \int_{-\infty}^{\infty} L(x, y) D_{m, n-m}(x-p, y-q) d x d y .
$$

As a result, the filter functions for the Hermite transform correspond to the Gaussian derivatives of the orders $m$ in $x$ and $(n-m)$ in $y$. Fig. 1 illustrates the Hermite-transform calculations performed for a phytoplankton species, with considerations of the transform order.

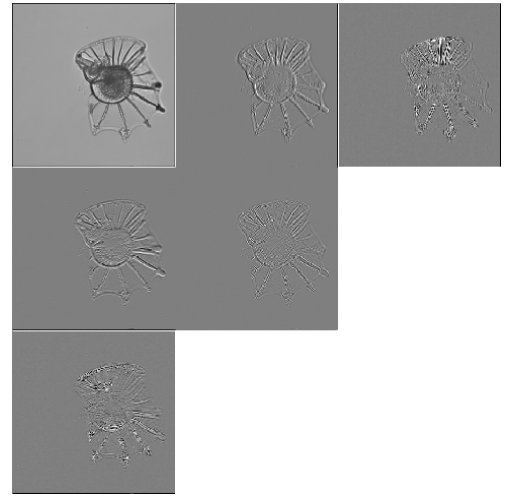

(a)

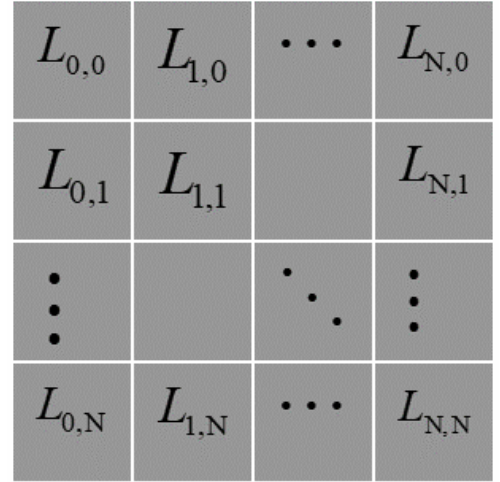

Fig. 1. (a) Hermite transform for a phytoplankton species and (b) a diagram that shows the coefficient orders.

There are many methods for calculating the performance of filters, which are based on socalled metrics [22]. In this work, we employ a known peak correlation energy metric (or PCE parameter) defined as [23]

$$
P C E=\frac{|E\{C(0,0)\}|^{2}}{E\left\{\overline{|C(x, y)|^{2}}\right\}},
$$

where $C(0,0)$ denotes the correlation value in the central plane, $C(x, y)$ the correlation value in $(x, y),|E\{C(0,0)\}|^{2}$ the square of the correlation peak, and $E\left\{\overline{|C(x, y)|^{2}}\right\}$ the square of the mean energy in the correlation plane.

\section{Hermite correlation and its optimal order}

The correlation methods are based upon the known correlation theorem, while the correlation plane is normalized using the Pearson correlation coefficient [24]. In this study, two types of correlations are used. First, it is the classical correlation, in which the images are Fourier transformed. Then the target image is conjugated and, finally, the inverse Fourier transform is applied (see Fig. 2a). In case if the correlation is calculated using the Hermite transform, the method can be called as a Hermite correlation. In this correlation, the Hermite transform of an optimal order must be used (see Fig. 2b).

Let us apply the Hermite transform to some input image. The transform can be successfully used in the correlation process after the optimal order is found (see Fig. 3). This is done after 
calculating all of the PCE values and selecting the optimal order such that its PCE is the highest (see Table 1). Notice that in our case the order $L_{1,1}$ is the highest. Let us use a Latin letter E (Arial font) as illustrated in Fig. 4. Comparing the correlation planes associated with the cases of no Hermite transform and the Hermite transform $L_{1,1}$, one can make certain that a much clearer pattern is obtained in the latter case. This order is further used as an optimal order for the correlation analysis.

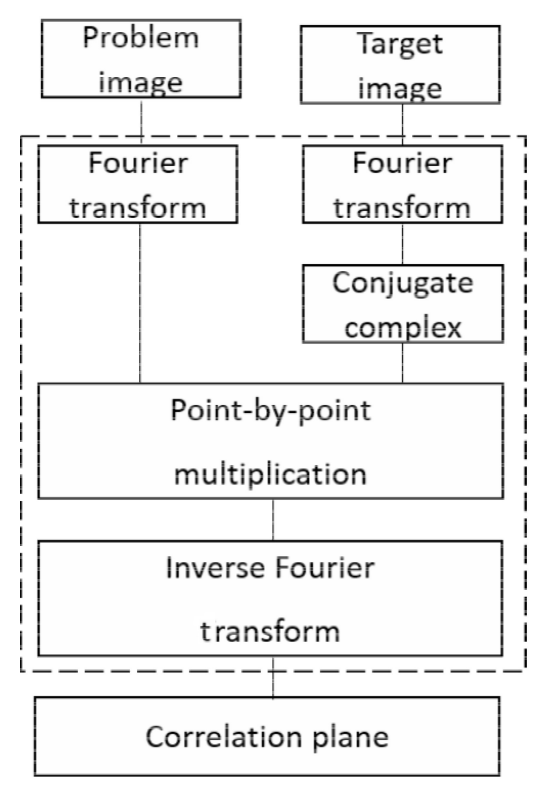

(a)

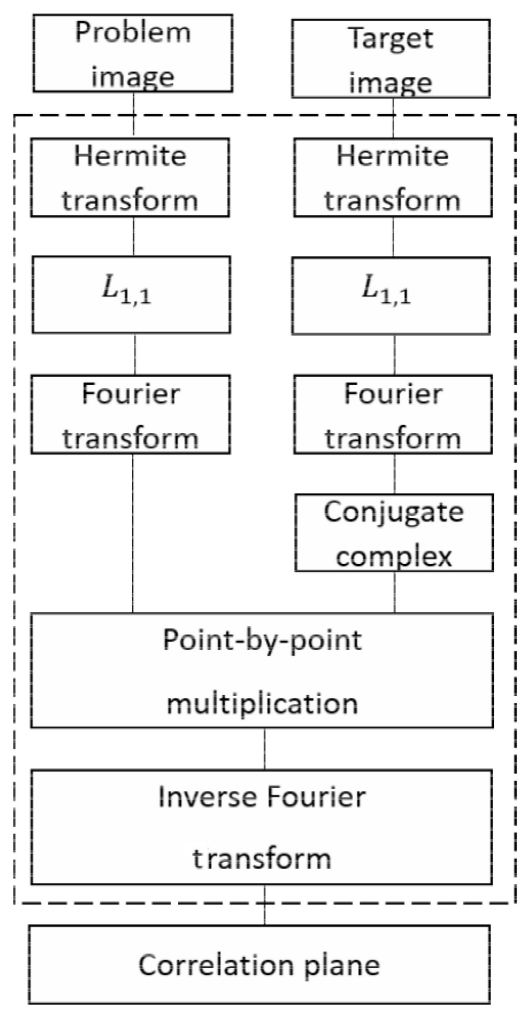

(b)

Fig. 2. Correlation diagrams for (a) classical and (b) Hermite correlations.

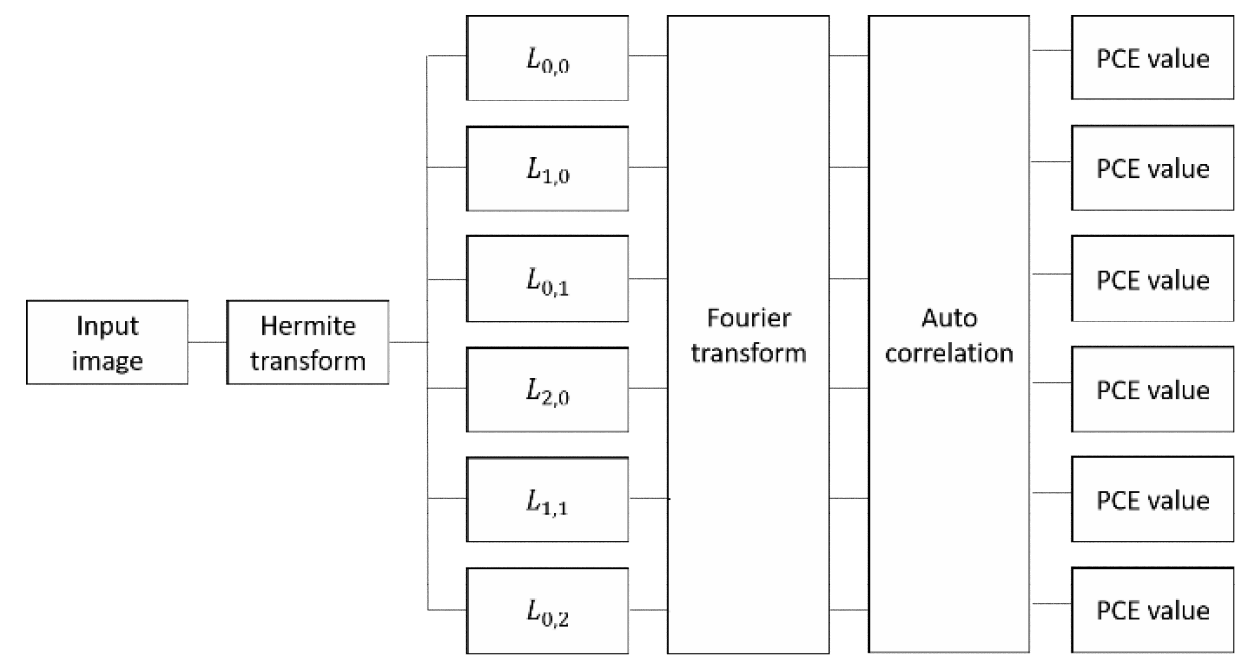

Fig. 3. Scheme of Hermite transforms of different orders applied to an image and the corresponding PCE values.

Ukr. J. Phys. Opt. 2018, Volume 19, Issue 2 
Table 1. PCE values associated with auto-correlation of Latin letter E.

PCE values found for letter E (Arial, font size $75,256 \times 256$ pixels)

\begin{tabular}{cccccccc}
\hline Order & $\begin{array}{c}\text { No Hermite } \\
\text { transform }\end{array}$ & $L_{0,0}$ & $L_{1,0}$ & $L_{0,1}$ & $L_{2,0}$ & $L_{1,1}$ & $L_{0,2}$ \\
\hline $\begin{array}{c}\text { PCE } \\
\text { value }\end{array}$ & $1.708 \times 10^{-6}$ & $1.34 \times 10^{-6}$ & $1.08 \times 10^{-4}$ & $3.51 \times 10^{-5}$ & $1.08 \times 10^{-4}$ & $3.83 \times 10^{-2}$ & $3.51 \times 10^{-5}$
\end{tabular}

\section{Correlation plane}

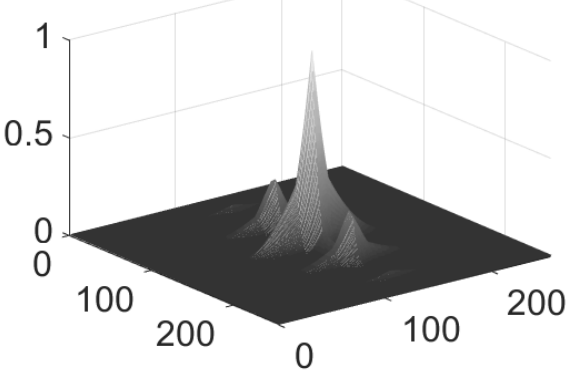

\section{Correlation plane}

(a)

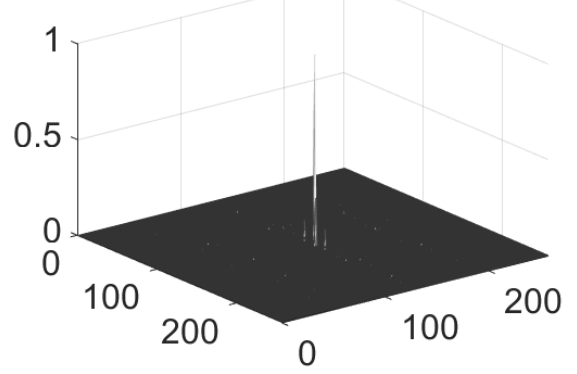

(b)

Fig. 4. Auto-correlation planes observed for letter $E$ in the cases when (a) no Hermite transform and (b) Hermite transform of the order $L_{1,1}$ are used.

\section{Influence of illumination patterns}

We have considered a number of illumination patterns to compare the performance of the classical and Hermite correlations (see Fig. 5). When a given illumination pattern is applied to each image (see Fig. 6), the value of every image pixel is modified by the pixel value corresponding to this illumination pattern. Then the influence of inhomogeneous illumination conditions can be studied using the simulations of variations in the pixel values of real images.

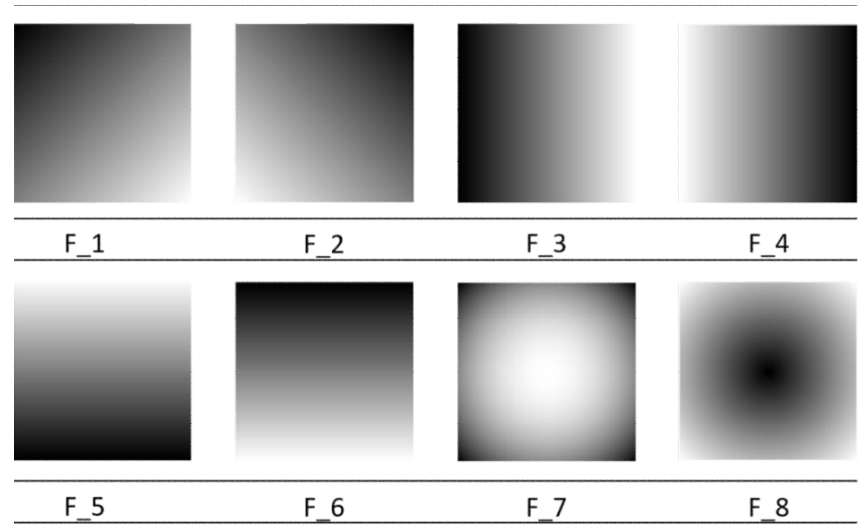

Fig. 5. Typical inhomogeneous illumination patterns analyzed in the present work.
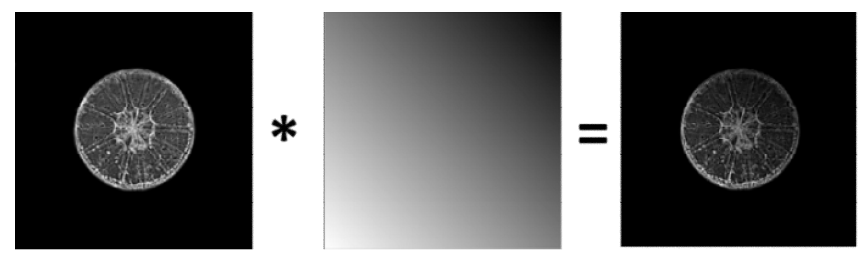

Fig. 6. Particular illumination pattern used in case of a phytoplankton species. 


\section{Classical composite filter}

Classical filters are not distortion-tolerant. In other words, if an image is deformed, as is the case with the most of real images, any matched filter fails. Then there is an alternative, a composite filter. These filters are created from representative images of objects, which are called 'training images' (see Fig. 7). The training images include different versions of rotation, scaling and illumination of a target to be recognized. In order to provide a high enough performance, one should reduce the number of the training images to less than 216 [25]. We have taken the training images and applied the Fourier transform to them. The appropriate results have been added, and then their complex conjugates have been calculated to create the classical composite filter. In our case this composite filter is a linear combination of the classical filters [26],

$$
H_{C M F}(u, v)=\sum_{n=1}^{N}\left|H_{n}(u, v)\right| \cdot e^{i \phi_{n}(u, v)},
$$

where $N$ is the number of the training images in the filter, $H_{n}(u, v)$ the Fourier transform of the $n$th target image, and $\phi_{n}(u, v)$ the phase of the $n$th image to be recognized.

In the first classical composite filter, the training images have been obtained by illuminating the same species with different patterns, while in the second case different specimens of the same species have been used as the training images. The training images have been preliminarily treated with the Hermite transform. The order $L_{1,1}$ has been taken to create the composite filter (see Fig. 8).

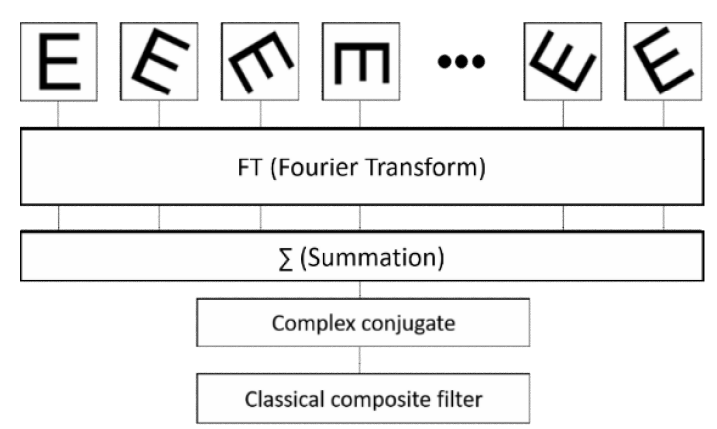

Fig. 7. Classical composite filter using the training images.

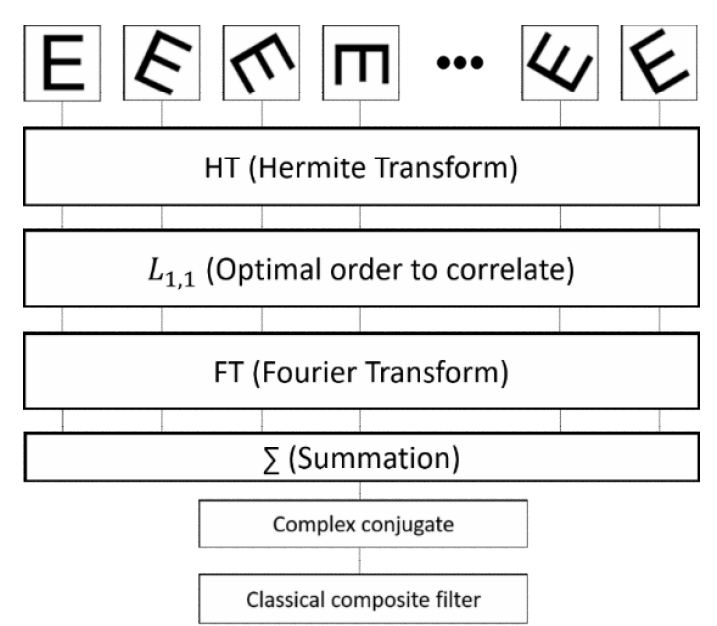

Fig. 8. Classical composite filter built on Hermite-based technique using the training images.

Ukr. J. Phys. Opt. 2018, Volume 19, Issue 2 


\section{Simulations, analyses and comparison of the results}

We have used the images of 30 different phytoplankton species (see Fig. 9). The correlations among these species have been calculated. This analysis has been performed using the two competing techniques mentioned before. Then the both techniques have been compared to make conclusions about the optimal one. The correlation values obtained for the first nine species in the frame of the two techniques are gathered in Table 2 and Table 3.

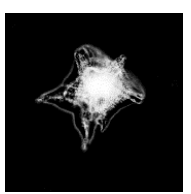

Species 1
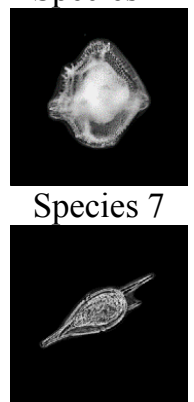

Species 13

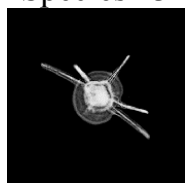

Species 19

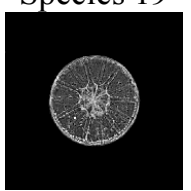

Species 25
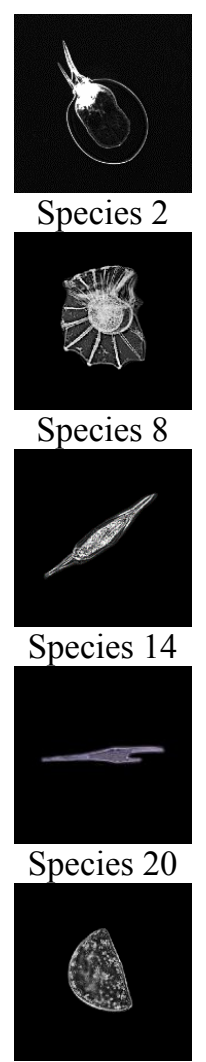

Species 26
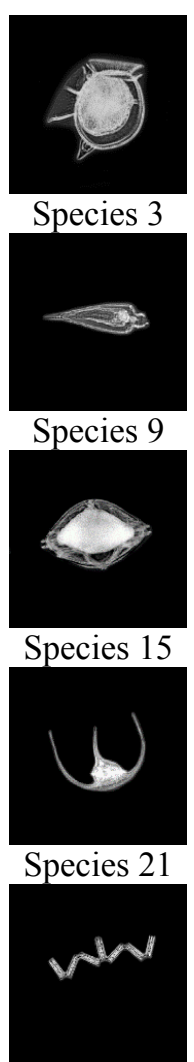

Species 27

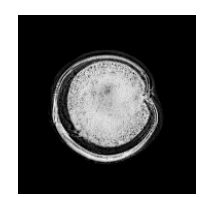

Species 4
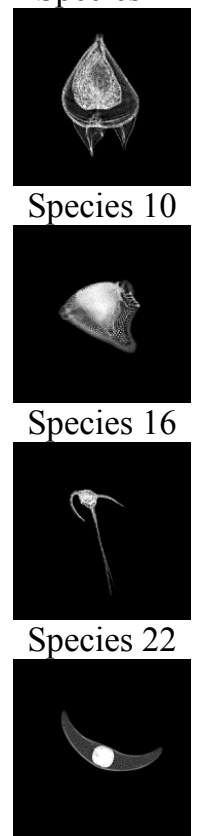

Species 28

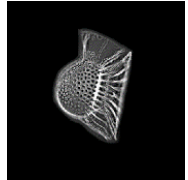

Species 5
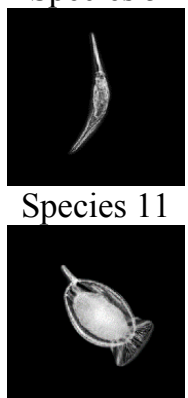

Species 17
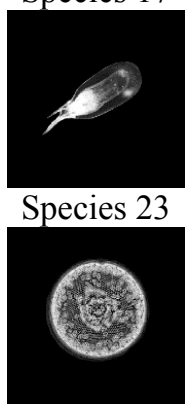

Species 29

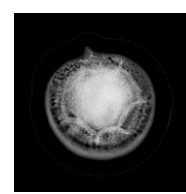

Species 6

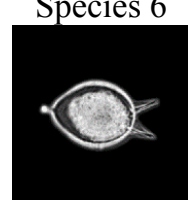

Species 12

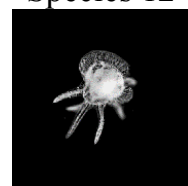

Species 18

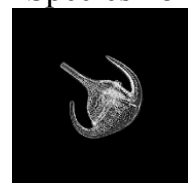

Species 24

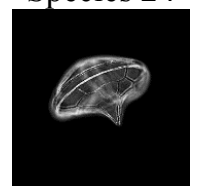

Species 30

Fig. 9. Phytoplankton species used in our correlation analysis: 1 - Acanthogonyaulax spinifera, 2 - Ceratium gravidum, 3 Dinophysis hastata, 4 - Diplosalopsis orbicularis, 5 - Histioneis, 6 - Lingolodinium polyedrum, 7 - Ornithocercu armata, 8 - Ornithocercus magnificus, 9 - Oxytoxum scolapax, 10 - Podolampas bipes 1, 11 - Podolampas Spinifer 1, 12 - Podolampas bipes 2, 13 -Podolampas palmipes, 14 - Podolampa spinifer 2, 15 - Protoperidinium, 16 - Dinophysis rapa, 17 - Dinophysis hastate, 18 - Ceratocorys horrida 1 , 19 - Ceratocorys horrida 2, 20 - Ceratium furca, 21 - Ceratium lunula, 22 - Ceratium hexacatum, 23 - Ceratium praelongum, 24 - Ceratium breve, 25 - Asterolampra marylandica, 26 - Hemidiscus cuneiformis, 27 - Thalassionema nitzschioides, 28 - Pyrocystis, 29 - Hemidiscus, and 30 - Dinoflagellata.

As seen from Table 2 and Table 3, the auto-correlations acquire the unit values. Although we can distinguish every species with the both techniques, the cross-correlation values for the case of the Hermite transform are smaller, if compared with those typical for the classical correlation. With these smaller correlation values, we arrive at a higher reliability level.

To probe the Hermite technique under conditions of inhomogeneous illumination patterns, we have calculated the correlations by the two techniques for comparing and discriminating different species. The image corresponding to the species 1 has been multiplied by eight illumination patterns, as shown in Fig. 10. Then we have calculated the correlations of these images with those corresponding to the same species but taken with no illumination pattern added 
using a classical filter (see Fig. 11). The correlations for the same species images with different illuminations are similar for the both techniques. However, the Hermite correlation produces smaller correlation values $\left(\sim 10^{-3}\right)$ in case of different species. This means that this correlation is better for distinguishing among the species (see Fig. 12).

Table 2. Correlations among the images of the first nine phytoplankton species (see Fig. 9) obtained using the classical correlation analysis.

\begin{tabular}{|c|c|c|c|c|c|c|c|c|c|}
\hline & \multicolumn{9}{|c|}{ Image (species) } \\
\hline & 1 & 2 & 3 & 4 & 5 & 6 & 7 & 8 & 9 \\
\hline- & 1 & 0.0805 & 0.5164 & 0.3819 & 0.3632 & 0.5227 & 0.4929 & 0.4344 & 0.2973 \\
\hline $\mathrm{N}$ & 0.0805 & 1 & 0.0991 & 0.1143 & 0.0935 & 0.1709 & 0.1347 & 0.1103 & 0.0726 \\
\hline \& $m$ & 0.5164 & 0.0991 & 1 & 0.5943 & 0.4776 & 0.6993 & 0.7193 & 0.4686 & 0.2863 \\
\hline & 0.3819 & 0.1143 & 0.5943 & 1 & 0.4855 & 0.8200 & 0.6514 & 0.4428 & 0.2021 \\
\hline$\sum_{=}^{\infty} n$ & 0.3632 & 0.0935 & 0.4776 & 0.4855 & 1 & 0.5442 & 0.5472 & 0.4135 & 0.1461 \\
\hline$\stackrel{\Xi}{=} 0$ & 0.5227 & 0.1709 & 0.6993 & 0.8200 & 0.5442 & 1 & 0.7710 & 0.5451 & 0.2800 \\
\hline$r$ & 0.4929 & 0.1347 & 0.7193 & 0.6514 & 0.5472 & 0.7710 & 1 & 0.5392 & 0.2980 \\
\hline$\infty$ & 0.4344 & 0.1103 & 0.4686 & 0.4428 & 0.4135 & 0.5451 & 0.5392 & 1 & 0.1752 \\
\hline$a$ & 0.2973 & 0.0726 & 0.2863 & 0.2021 & 0.1461 & 0.2800 & 0.2980 & 0.1752 & 1 \\
\hline
\end{tabular}

Table 3. Correlations among the images of the nine phytoplankton species (see Fig. 9) obtained using the Hermite transform of the order $L_{1,1}$.

\begin{tabular}{|c|c|c|c|c|c|c|c|c|c|}
\hline & \multicolumn{9}{|c|}{ Image (species) } \\
\hline & 1 & 2 & 3 & 4 & 5 & 6 & 7 & 8 & 9 \\
\hline 一 & 1 & 0.0003 & 0.0005 & 0.0001 & 0.0003 & 0.0002 & 0.0002 & 0.0002 & 0.0003 \\
\hline$N$ & 0.0003 & 1 & 0.0006 & 0.0001 & 0.0000 & 0.0001 & 0.0001 & 0.0001 & 0.0002 \\
\hline क्ष $m$ & 0.0005 & 0.0006 & 1 & 0.0005 & 0.0003 & 0.0001 & 0.0006 & 0.0003 & 0.0004 \\
\hline E. & 0.0001 & 0.0001 & 0.0005 & 1 & 0.0001 & 0.0003 & 0.0005 & 0.0003 & 0.0002 \\
\hline$\underbrace{\infty}_{=}$in & 0.0003 & 0.0000 & 0.0003 & 0.0001 & 1 & 0.0000 & 0.0000 & 0.0002 & 0.0001 \\
\hline$\stackrel{0}{=} 0$ & 0.0002 & 0.0001 & 0.0001 & 0.0003 & 0.0000 & 1 & 0.0003 & 0.0002 & 0.0001 \\
\hline I & 0.0002 & 0.0001 & 0.0006 & 0.0005 & 0.0000 & 0.0003 & 1 & 0.0000 & 0.0005 \\
\hline$\infty$ & 0.0002 & 0.0001 & 0.0003 & 0.0003 & 0.0002 & 0.0002 & 0.0000 & 1 & 0.0001 \\
\hline$a$ & 0.0003 & 0.0002 & 0.0004 & 0.0002 & 0.0001 & 0.0001 & 0.0005 & 0.0001 & 1 \\
\hline
\end{tabular}

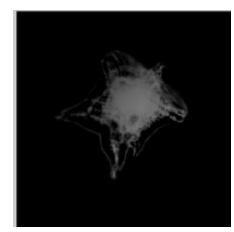

F 1

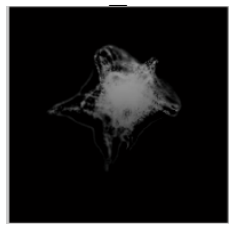

F_5

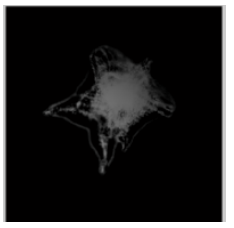

F 2

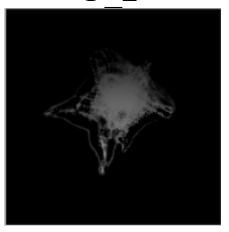

F_6

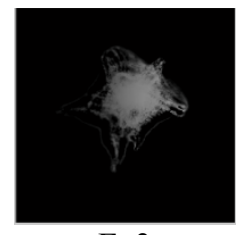

F 3

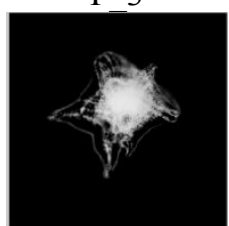

F_7

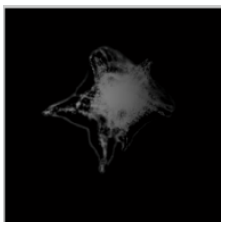

F 4

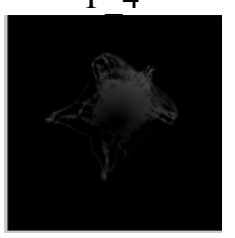

F_8

Fig. 10. Images of species 1 taken with eight illumination patterns added.

Since any real image involves distortions, one has to distinguish a target with these problematic images. To solve the problem, we need to evaluate our new technique. Using the phytoplankton images with real distortions (see Fig. 13), we have calculated the correlations

Ukr. J. Phys. Opt. 2018, Volume 19, Issue 2 
among the images of 22 phytoplankton species and compared the correlation values obtained using the both techniques. In Table 4 and Table 5 we present the correlation values typical for the first nine species.

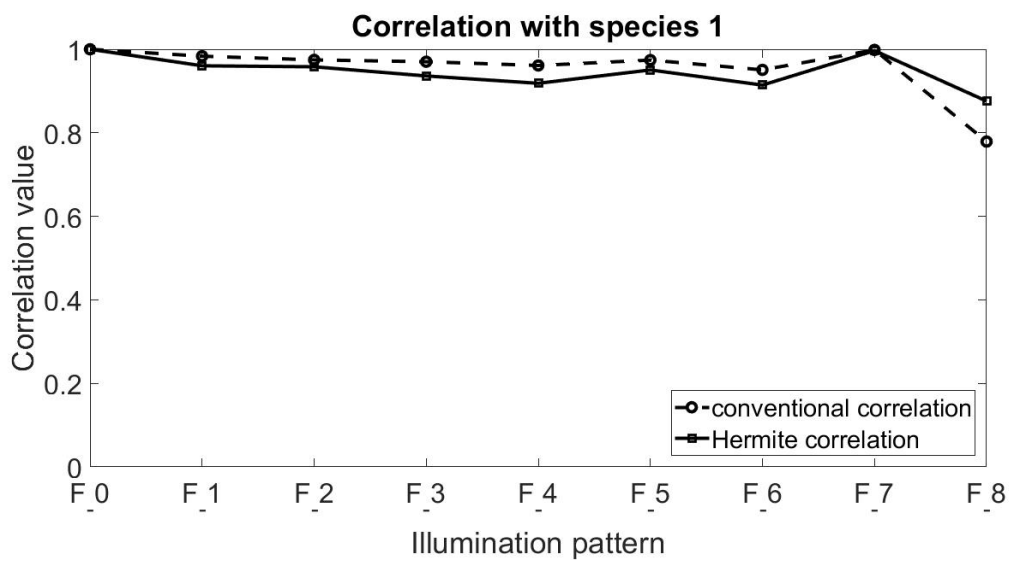

Fig. 11. Correlation values found among the images of same species with different illumination patterns: $F_{-} 0$ corresponds to the image with homogeneous illumination.

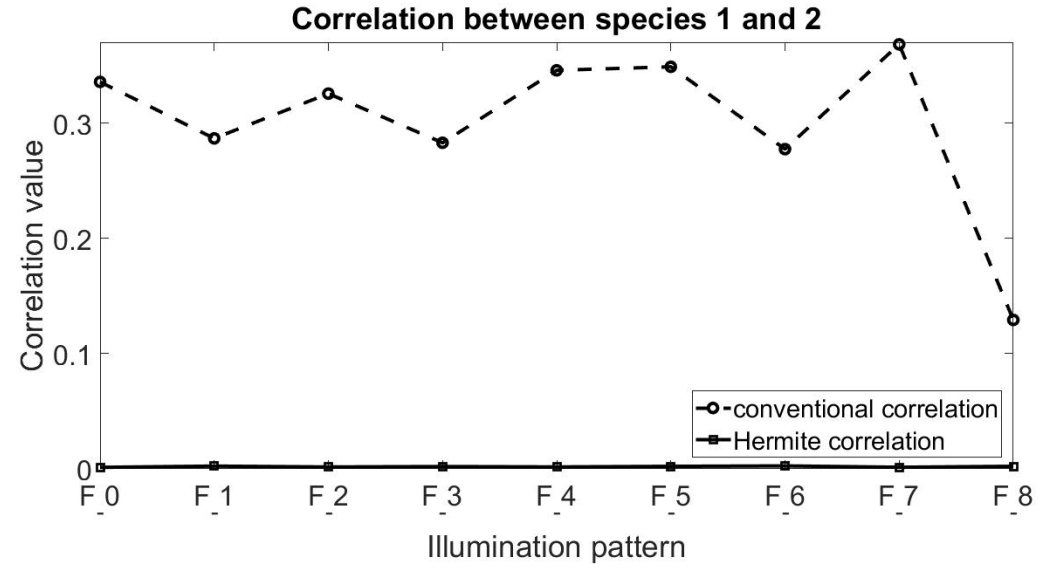

Fig. 12. Correlation values found among the image of species 1 (a target image) and the images of species 2 taken with eight illumination patterns.

Table 4. Correlation values found among the images of nine phytoplankton species using the classical correlation.

\begin{tabular}{|c|c|c|c|c|c|c|c|c|c|c|}
\hline & \multicolumn{9}{|c|}{ Image (species) } \\
\hline & & 1 & 2 & 3 & 4 & 5 & 6 & 7 & 8 & 9 \\
\hline \multirow{9}{*}{ 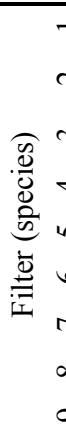 } & - & 1 & 0.0000 & 0.0167 & 0.0094 & 0.0245 & 0.0184 & 0.0174 & 0.0000 & 0.0207 \\
\hline & $\mathrm{N}$ & 0.0000 & 1 & 0.0011 & 0.0018 & 0.0046 & 0.0001 & 0.0195 & 0.0019 & 0.0002 \\
\hline & $m$ & 0.0167 & 0.0011 & 1 & 0.0005 & 0.0097 & 0.0002 & 0.0180 & 0.0001 & 0.0004 \\
\hline & t & 0.0094 & 0.0018 & 0.0005 & 1 & 0.0045 & 0.0017 & 0.0000 & 0.0031 & 0.0047 \\
\hline & & 0.0245 & 0.0046 & 0.0097 & 0.0045 & 1 & 0.0503 & 0.0002 & 0.0052 & 0.1140 \\
\hline & 。 & 0.0184 & 0.0001 & 0.0002 & 0.0017 & 0.0503 & 1 & 0.0437 & 0.0062 & 0.2867 \\
\hline & $r$ & 0.0174 & 0.0195 & 0.0180 & 0.0000 & 0.0002 & 0.0437 & 1 & 0.0277 & 0.0262 \\
\hline & $\infty$ & 0.0000 & 0.0019 & 0.0001 & 0.0031 & 0.0052 & 0.0062 & 0.0277 & 1 & 0.0060 \\
\hline & $a$ & 0.0207 & 0.0002 & 0.0004 & 0.0047 & 0.1140 & 0.2867 & 0.0262 & 0.0060 & 1 \\
\hline
\end{tabular}


Table 5. Correlation values found among the images of nine phytoplankton species using the Hermite transform of the order $L_{1,1}$.

\begin{tabular}{|c|c|c|c|c|c|c|c|c|c|}
\hline & \multicolumn{9}{|c|}{ Image (species) } \\
\hline & 1 & 2 & 3 & 4 & 5 & 6 & 7 & 8 & 9 \\
\hline- & 1 & 0.0002 & 0.0009 & 0.0002 & 0.0006 & 0.0003 & 0.0001 & 0.0005 & 0.0002 \\
\hline $\mathrm{N}$ & 0.0002 & 1 & 0.0009 & 0.0003 & 0.0009 & 0.0016 & 0.0018 & 0.0015 & 0.0029 \\
\hline$\overparen{n} m$ & 0.0009 & 0.0009 & 1 & 0.0004 & 0.0006 & 0.0007 & 0.0008 & 0.0017 & 0.0002 \\
\hline & 0.0002 & 0.0003 & 0.0004 & 1 & 0.0001 & 0.0006 & 0.0001 & 0.0002 & 0.0002 \\
\hline & 0.0006 & 0.0009 & 0.0006 & 0.0001 & 1 & 0.0017 & 0.0003 & 0.0013 & 0.0004 \\
\hline$\stackrel{\Phi}{ \pm} 6$ & 0.0003 & 0.0016 & 0.0007 & 0.0006 & 0.0017 & 1 & 0.0017 & 0.0029 & 0.0020 \\
\hline 空 & 0.0001 & 0.0018 & 0.0008 & 0.0001 & 0.0003 & 0.0017 & 1 & 0.0009 & 0.0001 \\
\hline$\infty$ & 0.0005 & 0.0015 & 0.0017 & 0.0002 & 0.0013 & 0.0029 & 0.0009 & 1 & 0.0014 \\
\hline$a$ & 0.0002 & 0.0029 & 0.0002 & 0.0002 & 0.0004 & 0.0020 & 0.0001 & 0.0014 & 1 \\
\hline
\end{tabular}

The cross-correlation values based on the Hermite transform are smaller, thus providing a higher reliability level of this technique (cf. the data of Table 4 and Table 5). Nevertheless, the main real problem is to identify different specimens of the same species. To probe this point, we have built two classical composite filters. The first one is made using varying patterns of illumination of the same species (see Fig. 10). The second filter, which is in fact multi-object, is made using different specimens as the training images (see Fig. 14).
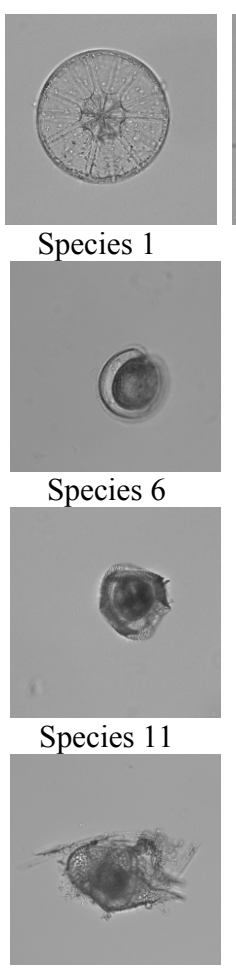

Species 17

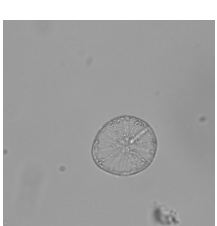

Species 2

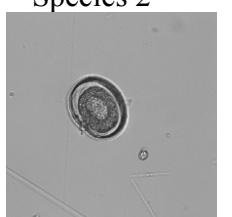

Species 6

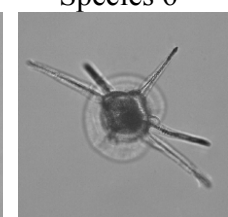

Species 12

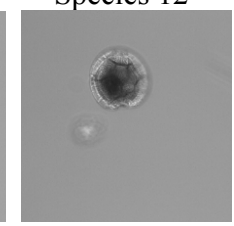

Species 18

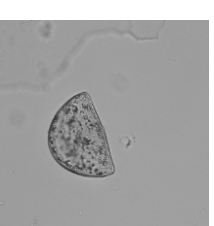

Species 3

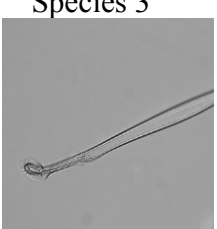

Species 7

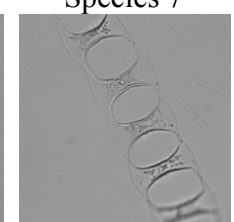

Species 13

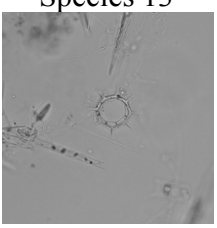

Species 19

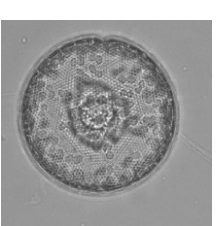

Species 4
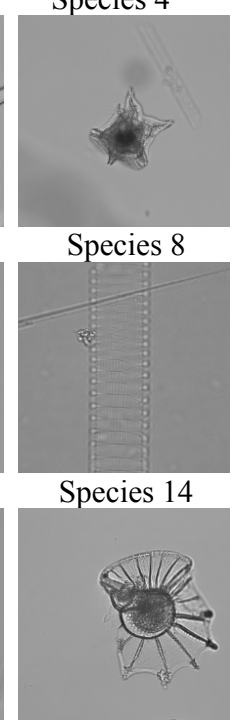

Species 20

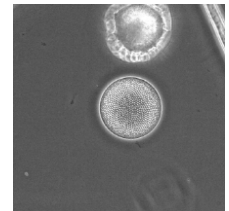

Species 5

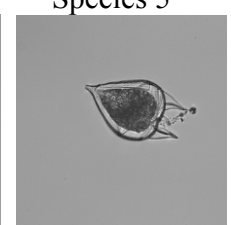

Species 9

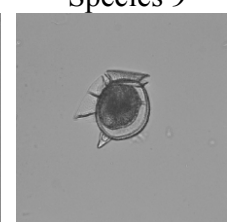

Species 15

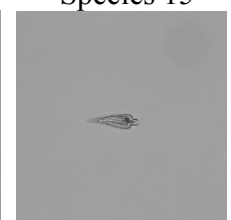

Species 21

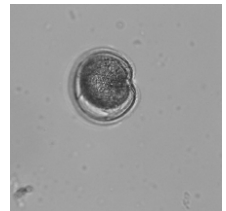

Species 6

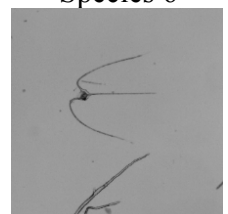

Species 10

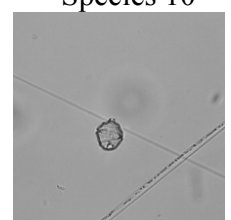

Species 16

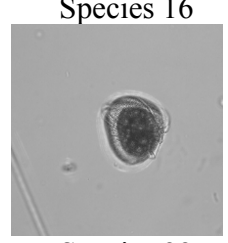

Species 22

Fig. 13. Images of phytoplankton species with real distortions used in our correlation analysis: 1 - Asterolampra marylandica, 2 - Asteromphalus heptactis, 3 - Hemidiscus cuneiformis, 4 - Hemidiscus, 5 - Odontella mobiliensis, - 6 - Diplosalopsis lenticulatum, 7 - Amphisolenia bidentata, 8 - Acanthogonyaul spinifera, 9 - Podolampas bipes, 10 - Ceratium macroceros, 11 - Ceratocorys armata, 12 - Ceratocorys horrida, 13 - Climacodium, 14 - Dactyliosolen antacticus, 15 - Dinophysis hastata, 16 - Goniaulax scippsae, 17 - Heterodinium, 18 - Linguloinium polyedrum, 19 - Octactis octonaria, 20 - Ornithocercus steinii, 21 - Oxytoxum scolapax, and 22 - Phalacroma cuneus.

Ukr. J. Phys. Opt. 2018, Volume 19, Issue 2 

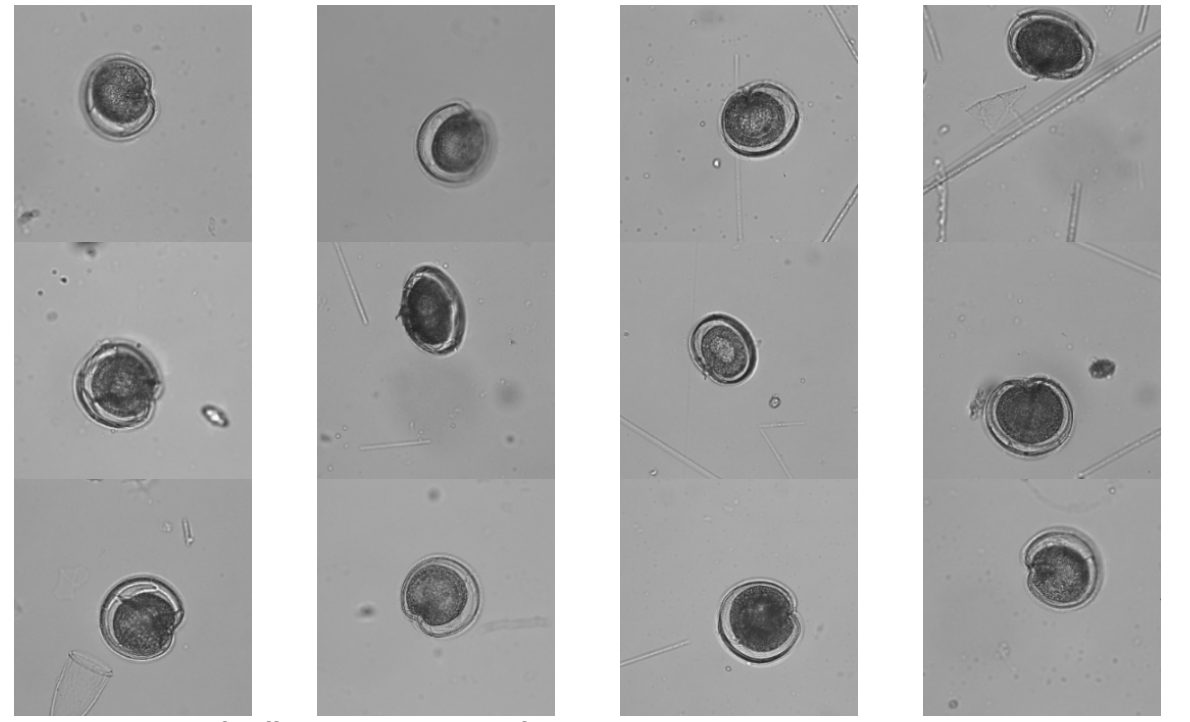

Fig. 14. Images of different specimens of the species Diplosalopsis lenticulatum used in the classical composite filter.

In Fig. 15 one can see nine bars that correspond to different species. The first bar refers to the image with no variations of illumination and the others to inhomogeneous illuminations illustrated in Fig. 5. Using the classical composite filter, we have compared the correlation values among the images of each of the species and the eight images with illumination variations. This has been done in the frame of the both techniques. Using the classical technique and a composite filter based on illumination variations for the species 6 , we have found the correlations for the first ten species. The classical correlation suffers difficulties in distinguishing among the target species and the species 7 (see Fig. 15). In case of the same filter with the Hermite correlation, all the species can be easier identified because the correlation values for the other species are smaller $\left(\sim 10^{-3}-\right.$ see Fig. 16).

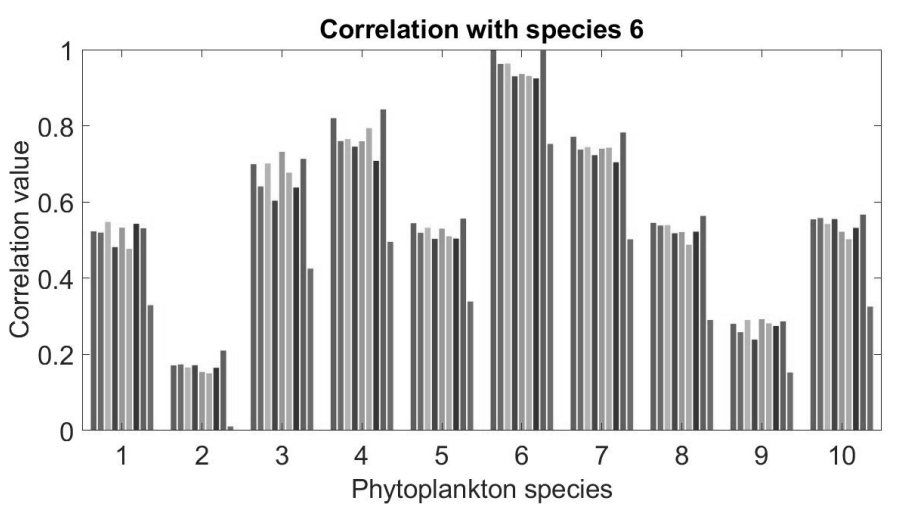

Fig. 15. Correlation values obtained using the classical composite filter and the classical correlation technique.

Using the classical composite filter, we have found the cross-correlations among different species of which images are shown in Fig. 13. The correlation values have been compared for the two techniques under analysis. The classical correlation fails to identify the target species that correspond to dotted bars in Fig. 17. On the other hand, the Hermite transform of the order $L_{1,1}$ provides a possibility to distinguish these species (see Fig. 18). In Fig. 17 and Fig. 18 showing the images of different species and specimens, the correlation values for the samples $6,7,8$ and 9 are 
higher than those for the others samples. Although the target specimens could not be distinguished using the classical correlation, the Hermite method enables one to identify successfully every target specimen.

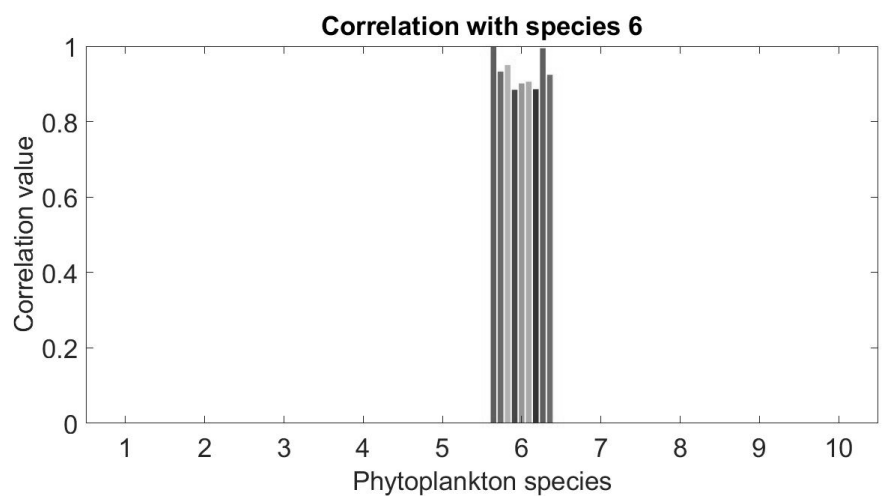

Fig. 16. Correlation values obtained using the classical composite filter and the Hermite-correlation technique..

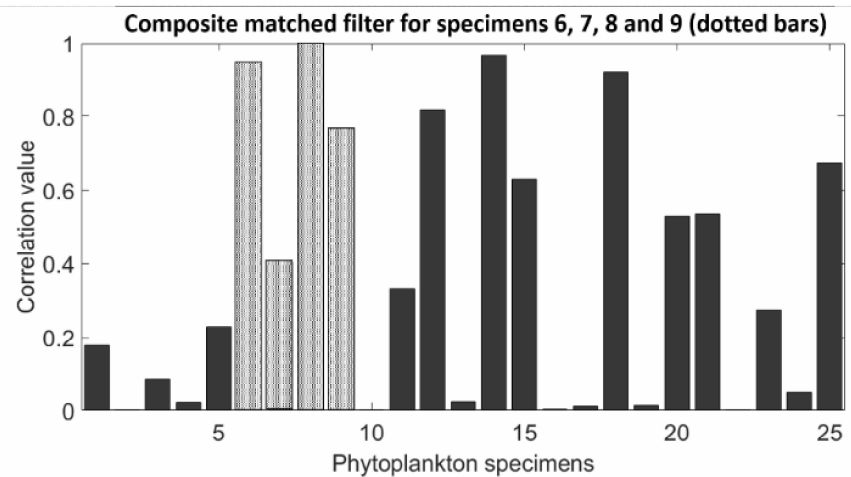

Fig. 17. Correlation values among the images of phytoplankton species found using the classical composite filter with the classical correlation.

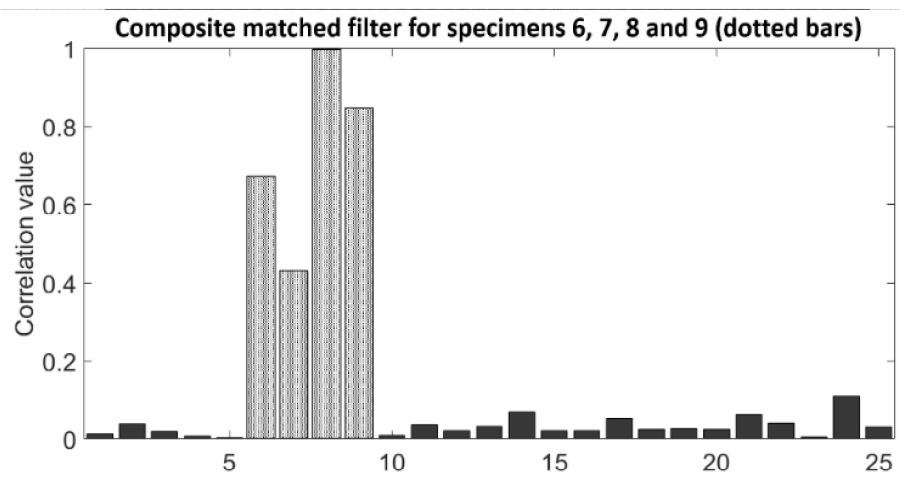

Fig. 18. Correlation values among the images of phytoplankton species found using the classical composite filter with the Hermite transform of the order $L_{1,1}$.

Now we return to Fig. 2a and Fig. $2 b$ that compare the schemes of the classical and Hermite correlations from a technical viewpoint. The runtimes are equal to $0.0331 \mathrm{~s}$ and $0.1420 \mathrm{~s}$ for the techniques based on the classical and Hermite correlations, respectively. These times correspond to an HP Notebook with a processor $2.20 \mathrm{GHz}$ AMD A8 and 12 GB RAM. In principle, the both 
techniques could recognize the images. However, the Hermite correlation manifests a higher reliability level when the images displayed in Fig. 9 and Fig. 13 are used.

We have also tested the influence of noise added to the images upon the performance of the two competing techniques. Contrary to the conventional correlation with the classical filter, the Hermite transform is not so noise-immune. This is readily understood since the Hermite transform selects only a part of the total information on images. Summing up, the both techniques can distinguish the problematic images with the Gaussian noise whenever the variance is as large as unity. Moreover, the classical technique can identify the images even under the conditions of very dense noise (including impulse one) as high as 95\%, while the Hermite technique is supported under the conditions of less than $65 \%$ noise density.

\section{Conclusion}

In the present work, we have compared the classical correlation versus the Hermite correlation techniques. The auto-correlations for the group of images associated with phytoplankton species have been calculated to find out the optimal order of the Hermite transform necessary for the efficient recognition process. For this aim we have evaluated the corresponding PCE values and compared them to each other. Our analysis has demonstrated that the optimal order corresponds to $L_{1,1}$.

The main methodological results of the present study have been tested using the two phytoplankton groups. The first one includes the phytoplankton images with black background and no distortions. The second group involves the images with natural distortions, different background noises and inhomogeneous illumination.

In principle, the two techniques can distinguish different species in the both cases. However, the Hermite correlation generally provides higher reliability levels in the species recognition, especially in case if the phytoplankton images from the first group are characterized by inhomogeneous illumination patterns. It is noteworthy that identification of the phytoplankton species issuing from their specimens has proven to be impossible with the classical correlation. Nonetheless, the results appear to be successful in every case when the Hermite correlation is used.

\section{Acknowledgments}

This study has been included in the thesis supported by CONACyT under the scholarship 591816. Alfredo Castro-Valdez is a student of Ph.D. program of the Optics Department in CICESE and CONACyT's scholarship with CVU: 690311. We thank Dr. Boris Escalante Ramirez for sharing the program generating the Hermite transform.

\section{References}

1. Vander Lugt A, 1964. Signal detection by complex spatial filtering. IEEE Trans. Inf. Theory. 10: $139-145$.

2. Solorza S and Álvarez-Borrego J, 2009. System of digital invariant correlation to rotation applied to identify car models. Digital Scientific and Technological Journal, e-Gnosis, ISSN 1665-5745.

3. Yue Gao, Teng Cheng, Yong Su, Xiaohai Xu, Yong Zhang, Qingchuan Zhang, 2015. Highefficiency and high-accuracy digital image correlation for three-dimensional measurement. Opt. Las. Eng. 65: 73-80.

4. Tong W, 2005. An evaluation of digital image correlation criteria for strain mapping applications. Strain. An International Journal for Experimental Mechanics, 41: 167-175. 
5. Fimbres-Castro C, Álvarez-Borrego J and Bueno-Ibarra MA, 2012. Invariant nonlinear correlation and spectral index for diatoms recognition. Opt. Eng. 51: 047201.

6. LeFeuvre P, Rose GA, Gosine R, Hale R, Pearson W, Khan R, 2000. Acoustic species identification in the Northwest Atlantic using digital image processing. Fisheries Research 47: 137-147.

7. Solís-Ventura A, Álvarez-Borrego J and Solorza S, 2015. Adaptive nonlinear correlation with a binary mask invariant to rotation and scale. Optics Communications. 339: 185-193

8. Sachs C, Fabritius H, Raabe D, 2006. Experimental investigation of the elastic-plastic deformation of mineralized lobster cuticle by digital image correlation, Journ. Struct. Biol. 155: 409-425.

9. Spampinato C, Giordano D, Di Salvo R, Yun-Heh Jessica Chen-Burger, Fisher R B, Nadarajan G, 2010. Automatic fish classification for underwater species behavior understanding, Proceedings of the first ACM international workshop on analysis and retrieval of tracked events and motion in imagery streams, Firenze, Italy.

10. Bueno-Ibarra MA, Chávez-Sánchez MC and Álvarez-Borrego J, 2011. K-law spectral signature correlation algorithm to identify white spot syndrome virus in shrimp tissues. Aquaculture 318: 283-289.

11. Guerra-Rosas E and Álvarez-Borrego J, 2015. Methodology for diagnosing of skin cancer on images of dermatologic spots by spectral analysis. Biomed. Opt. Exp. 6: 3876-3891.

12. Guerra-Rosas E, Álvarez-Borrego J and Angulo-Molina A, 2017. Identification of melanoma cells: a method based in mean variance of signatures via spectral densities. Biomed. Opt. Exp. 8: $2185-2194$.

13.Estudillo-Romero A, \& Escalante-Ramirez B, 2008. The Hermite transform: an alternative image representation model for Iris recognition. In Iberoamerican Congress on Pattern Recognition. Springer: Berlin Heidelberg, pp. 86-93.

14.Leiner Barba-J, Ernesto Moya-Albor, Boris Escalante-Ramírez, Jorge Brieva, Enrique Vallejo Venegas, 2016. Segmentation and optical flow estimation in cardiac CT sequences based on a spatiotemporal PDM with a correction scheme and the Hermite transform, Comp. Biol. Med. 69: $189-202$.

15.Lorena Vargas-Quintero, Boris Escalante-Ramírez, Lisbeth Camargo Marín, Mario Guzmán Huerta, Fernando Arámbula Cosio, Héctor Borboa Olivares, 2016. Left ventricle segmentation in fetal echocardiography using a multi-texture active appearance model based on the steered Hermite transform, Comp. Meth. Progr. Biomed. 137: 231-245.

16. Escalante-Ramırez B, \& López-Caloca A A, 2007. The Hermite transform: an efficient tool for noise reduction and image fusion in remote-sensing. Image Process. Rem. Sens. 273: 537-555.

17.Escalante-Ramírez B, 2008. The Hermite transform as an efficient model for local image analysis: An application to medical image fusion. Comp. Electr. Engin. 34: 99-110.

18. Srinivasan Nirmala, 2012. Cross-correlation of biomedical images using two dimensional discrete Hermite functions. Diss. University of Akron.

19. Sanchez Luna V, 2008. Indexado de imágenes aplicando la transformada polinomial, Tesis de maestría. Universidad Nacional Autónoma de México.

20. Mackenzie M R, \& Tieu A K, 2003. Hermite neural network correlation and application. IEEE Transact. Signal Process. 51: 3210-3219.

21. Martens J B, 1990. The Hermite Transform - Theory. IEEE Transact. Acoust. Speech and Signal Process. 38: 1607-1618.

Ukr. J. Phys. Opt. 2018, Volume 19, Issue 2 
22. Vijaya Kumar B V K and Hassebrook L, 1990. Performance measures for correlation filters. Appl. Opt. 29: 2997-3006.

23. Javidi B, 1989. Nonlinear joint power spectrum based optical correlation, Appl. Opt. 28: 23582367.

24. Benesty J, Chen J, Huang Y and Cohen I, 2009. Pearson Correlation Coefficient. In: Noise Reduction in Speech Processing, Springer, Heidelberg, 37-40.

25. Ricardo Enrique Guerrero Moreno and Josué Álvarez Borrego, 2009. Nonlinear composite filter performance. Opt. Eng. 48: 067201.

26. Casasent D, 1984. Unified synthetic discriminant function computational formulation. Appl. Opt. 23: 1620-1627.

Castro-Valdez A. and Álvarez-Borrego J. 2018. Identification of phytoplankton species using Hermite transform. Ukr.J.Phys.Opt. 19: 106-120

Анотація. Ми поєднали перетворення Ерміта з класичним кореляційним аналізом для розпізнавання різних видів фітопланктону. Розпізнавання виявилося успішним навіть у тих складних випадках, коли відповідні зображення характеризуються неоднорідним висвітленням і природними спотвореннями. Зображення видів фітопланктону поділено на дві групи, кожна з яких складається з 30 проб. Ті, щзо відносяться до першої групи, - ие зображення, для яких відсутні неоднорідне освітлення та иуми, а до другої входять зображення із фоновими шумами, неоднорідним освітленням і спотвореннями. Знайдено оптимальний порядок перетворення Ерміта, який слід використовувати для пошуку кореляцій між зображеннями. Це дає так звана метрика енергї пікових кореляцій. Використовуючи зображення, модифіковані перетворенням Ерміта з класичним фільтром Вандер-Люгта, ми одержали змогу розрізнити всі види фітопланктону в тестових зображеннях. Класичний композитний фільтр також застосовано до двох груп зображень. Для першої групи композитний фільтр було створено за допомогою різних картин підсвічування того ж виду. Для другої групи ией фільтр сформовано на основі різних зразків того ж виду для ідентифікації конкретного виду. В обох випадках перетворення Ерміта в поєднанні з класичним корелячійним аналізом дає змогу розпізнати всі види фітопланктону. 